\title{
Polish camp literature. A few questions about a synthesis that is missing
}

There are at least three reasons why there has never been a historical and literary synthesis regarding Polish camp literature. The first reason is the Lager prose by Tadeusz Borowski. The second is the Holocaust literature written in Polish. The third is a result of the differences between camp literature written domestically and abroad.

\section{Protosyntheses of Polish Gulag literature}

The complexity of the situation is amplified by the fact that the absence of a synthesis of Polish Lager literature coincides with the presence of syntheses, or at least protosyntheses, of Polish Gulag literature. I am referring to the diversely evaluated study by Eugeniusz Czaplejewicz, ${ }^{1}$ the monograph by Izabella Sariusz-Skąpska entitled Polscy świadkowie GUŁagu, ${ }^{2}$ and to more specialist and specific publications, e.g. Doświadczenie Boga w Gułagu by a Dominican Andrzej Morka. ${ }^{3}$ The syntheses/protosyntheses of Polish Gulag literature exist because its chief writer, i.e. Gustaw Herling-Grudziński, was not an author different from other writers raising that topic. His vision of Gulag corresponds with that recorded by other Polish writers ${ }^{4}$ it is heroic and martyrological, humanistic and moralistic, and Polish. Its coherence, unlike in the case of Lager literature, is not disturbed by an experience comparable to the Holocaust. Additionally, due to

* Professor; Chair of Interwar and Contemporary Polish Literature, Institute of Polish Philology, University of Białystok, Pl. Uniwersytecki 1, 15-420 Białystok; ifp@uwb.edu.pl.

${ }^{1}$ Vide E. Czaplejewicz, Polska literatura lagrowa, PWN, Warsaw 1992.

${ }^{2}$ Vide I. Sariusz-Skąpska, Polscy świadkowie GUŁagu. Literatura łagrowa 1939-1989, Universitas, $3^{\text {rd }}$ edition, Krakow 2012. Originally printed in: 1995, $2^{\text {nd }}$ edition: 2002.

${ }^{3}$ Vide A. Morka, Doświadczenie Boga w Gułagu, Wydawnictwo Diecezjalne, Sandomierz 2007.

${ }^{4}$ The reproducibility and the durability of that vision are not altered by such texts as Marian Czuchnowski's novel entitled Tyfus, teraz stowiki (London 1951), though it discusses not so much a camp as a Soviet hospital, while that place, even in Borowski's writings as well as throughout Lager-Gulag literature, is often a safe haven within a sea of camp death. 
reasons political in nature, the shape of Polish Gulag literature, mainly its diversity, was decided upon by émigré writers.

The above-mentioned reasons, which are antithetically related to the reasons for the non-existence of a synthesis of Polish camp literature, could be supplemented with others. I shall limit myself to two additional ones, somewhat blurred and controversial, indirectly influencing the existence of synthetic studies of Gulag literature. The first one: the writing about emigration belles-lettres, on Gulag literature in particular, not only fictional, has been defined since 1989 by a special commitment to its authors: absent from Poland after 1944, both in the country and in domestic literary studies. That writing serves to liberate oneself from the sense of guilt, and to maintain the highest Polish correctness, a particularly important example of which being Próba scalenia by Taduesz Drewnowski. ${ }^{5}$ The second reason: Gulag literature confirms our positive opinion of ourselves. Not only does it match the Romantic (martyrological and messianic) standard of our experiencing of history, but it also enables Poles to experience anew their cultural superiority over the Soviet oppressor.

\section{Tadeusz Borowski}

Although, considering the topic, this might not appear appropriate, it is not extremely flippant to ask: why would we need a synthesis of Polish camp literature when we continue to receive new studies of Tadeusz Borowski's Lager literature? In fact, any, especially literary text raising the camp theme, is, happens to be, or even should be read in relation to Pożegnanie z Maria and Kamienny świat. Borowski equals Polish camp literature because no one has ever said more about the camps than he, and has never done it using more original or appropriate literary solutions.

To say the most mainly means to reach the essence of the camp experience, the unimaginable, perfectly orchestrated crime, which has changed the definition of humanity weighing not only on the oppressors, but on the victims as well, and it constitutes a moral challenge for anyone who has come into contact with it, even through literature. To say the most also means to write a fragmented work, divided into stories (Pożegnanie z Maria), and short stories (Kamienny świat), yet epic in nature, i.e. enabling a reconstruction of the camp ordeal from arriving at the Auschwitz ramp (e.g. This Way for the Gas, Ladies and Gentlemen), through the extermination of Hungarian Jews (Ludzie, którzy szli), to the ambiguous liberation (e.g. Milczenie), and the time spent in a DP camp (e.g. Spotkanie z dzieckiem or Bitwa pod Grunwaldem).

${ }^{5}$ Vide T. Drewnowski, Próba scalenia. Obiegi - wzorce - style, PWN, Warsaw 1997. Vide ibid., Literatura polska 1944-1989. Próba scalenia: obiegi - wzorce - style, $2^{\text {nd }}$ edition amended, Universitas, Krakow 2004. 
For many years now I have been a proponent of the thesis that a condition for the functioning of Polish literature after WWII was for it to be written down, which required two conditions to be fulfilled. It was necessary to show the wartime/occupation heart of darkness, and to do it in a way not previously used by Polish writers. Tadeusz Różewicz and Taduesz Borowski did the most in that respect. I am forced to omit the former as I am discussing the camp theme. The latter recorded the camp and did that utilising the behavioural technique, ${ }^{6}$ which had never been used before in Polish literature on such an extensive scale. Thus he enabled Polish literature to function after WWII, and recorded the camp: in the fullest, most original, and appropriate way, considering the behavioural solutions he decided to utilise.

In relation to Borowski's Lager texts, the entirety of Polish literature is either secondary or derivative. As early as $1971^{7}$ the relationship between Pożegnanie $z$ Maria and the remainder of camp literature was defined by Andrzej Werner, who introduced the category of "martyrological literature". ${ }^{8}$ Since the publishing of Zwyczajna apokalipsa there has been either Borowski or a whole host of authors helpless when confronted with the camp experience, who in relation to Lagers copied the Romantic templates of taming national failures. The outcomes of their efforts were disparaged by Tadeusz Borowski the writer, e.g. in Bitwa pod Grunwaldem, and Tadeusz Borowski the literary critic in Alicja w krainie czarów. ${ }^{9}$

In time, Polish camp literature ceased to be exclusively martyrological, yet the conclusion rather seems an expression of wishful thinking than of an actual state of affairs. What texts could actually be quoted to confirm it? Would $Z \mathrm{Au}$ szwicu do Belsen by Marian Pankowski, ${ }^{10}$ a special émigré, because not residing in Paris, London or New York, but in Brussels, suffice? The situation is different. Camp literature not so much ceased to be martyrological, as it started to be appreciated, or at least treated as a "special type of historical writings". ${ }^{11}$ That change was largely caused by Bartłomiej Krupa's book founded on a conviction that the exceptionality of the Holocaust gives each work which discusses it, regardless of its literary value, the status of a priceless document, and an invaluable proof. Thus

${ }^{6}$ I discuss that in more detail in a book entitled Dwie prawdy. Tadeusz Borowski $i$ Zofia Kossak wobec obrazu wojny w polskiej prozie lat 1944-1948, Trans Humana, Białystok 2006.

7 "As early as" from the perspective of the $21^{\text {st }}$ c., yet "only in" from the point of view of the date of the end of WWII.

${ }^{8}$ Vide A. Werner, Zwyczajna apokalipsa. Tadeusz Borowski i jego wizja świata obozów, Czytelnik, Warsaw 1971.

${ }^{9}$ Vide T. Borowski, “Alicja w krainie czarów”, Pokolenie 1947, issue 1. First book edition of the review in: ibid., Utwory zebrane, J. Andrzejewski (ed.), vol. 3: Krytyka literacka i artystyczna, PIW, Warsaw 1954, pp. 21-31.

${ }^{10}$ Vide M. Pankowski, Z Auszwicu do Belsen. Przygody, Czytelnik, Warsaw 2000.

${ }^{11}$ Vide B. Krupa, Wspomnienia obozowe jako specyficzna odmiana pisarstwa historycznego, Universitas, Krakow 2006. 
justified treatment of Shoah had at least an indirect influence on the evaluation of Polish Lager literature with a martyrological nature. ${ }^{12}$

\section{The Holocaust}

When recording the apocalyptic nature of concentration camps, Borowski did not emphasise in it the exceptional fate of Jews more than as a part of a coherent vision of Lager reality. As a result, the camp absorbed the Holocaust, while Polish literature, having at its disposal the masterpieces of Lager belles-lettres, did not cope with it. With one exception: the same judgement did not apply either to Polish writers of Jewish descent or Jewish writers of Polish descent, ${ }^{13}$ because their texts were not literature which described the camp, but rather texts relatable to the Shoah experience. ${ }^{14}$

Therefore, the matter is as follows: on the one hand, there is the record of the camp, which is sometimes treated as a symbol of Shoah, though its image in Polish literature cannot confirm that association as it focusses either on the heroic martyrdom of Poles (martyrological literature), or on the perfect operation of the camp mechanism dehumanising everyone, both the oppressors and the victims (Borowski); on the other, there is the Holocaust literature written by Jews in various ways connected with Poland, in which the camp, if present at all, plays a secondary role. ${ }^{15}$

Sadly, though, the equation (one hand vs. the other) offers no solace, or dialectic stability. On the contrary: there is disparity and dissonance in it. The disparity applies to the relationship between the recording of the war, the camp, and the lack of a record of the Holocaust. It seems that we have fooled history, literature, and ourselves: we, Poles. We did that by recording WWII thanks to Borowski's Lager prose, yet without tackling or even raising the topic of Shoah. ${ }^{16}$ How is that

${ }^{12}$ The paradox results from the fact that the literature, being focussed on the martyrology of Poles, does not consider the exceptionality of the camp fate of Jews.

${ }^{13}$ Vide Pisarze polsko-żydowscy XX wieku. Przybliżenia, M. Dąbrowski and A. Molisak (eds.), Elipsa, Warsaw 2006. That collective monograph once again offered a division into Polish writers of Jewish descent, and Jewish writers of Polish descent. The former were defined movingly by Artur Sandauer in a book which was written based on a well-known article published in the $\dot{Z} y c i e$ Literackie journal, bearing the same title as the article: O sytuacji pisarza polskiego pochodzenia żydowskiego $w$ XX wieku (rzecz, która nie ja powinienem byt napisać...), Warsaw 1982. The latter were a group with which Bogdan Wojdowski identified, the author of, e.g. the excellent epic novel about the Warsaw ghetto: Chleb rzucony umarlym, and of only a slightly lesser known text "Judaizm jako los" (Puls 1993, issue 3).

${ }^{14}$ I discussed those texts in the chapter "Polska proza o Zagładzie i emocje. Rekonesans", which was a part of my book entitled $W$ poszukiwaniu istoty rzeczy. Studia i portrety (Katedra Badań Filologicznych „Wschód-Zachód”. Wydział Filologiczny, Białystok 2015).

${ }^{15}$ Even if it is a terrifying point of reference as in Oczekiwanie by Jerzy Broszkiewicz. Vide ibid., Oczekiwanie, Wiedza, Warsaw 1948.

${ }^{16}$ Adolf Rudnicki was aware of the necessity to write about Shoah, and a writer's helplessness in relation to the topic (vide A. Rudnicki, "Piękna sztuka pisania", in: ibid., Szekspir, Książka, 
possible? How could anyone have created an illusion of recording WWII without recording Shoah? The answers which abuse in that matter the issue of (un)presented trauma ${ }^{17}$ do not seem sufficient for me. I find the only exculpation/justification of that state of things in the masterpiece nature of the Lager prose of Tadeusz Borowski, and in the fact that its author, exceptionally acutely identifying the mechanisms of the functioning of KL Auschwitz-Birkenau, efficiently destroying the Mediterranean civilisation, was focussed on them exactly.

That does not change the fact that the dissonance lingers. The dissonance between the Jewish Lager fate, and Borowski's prose, and, consequently, between Polish camp literature, and the Polish-Jewish literature of the Holocaust. The former could be collectively branded with the slogan: "People dealt this fate to people". The latter, not only when it can be assigned to Henryk Grynberg, should be branded with the caption: "People dealt this fate to Jews". Because the camp, even if described with the utmost precision, cannot absorb Shoah. It cannot obscure it. I do not know whether literature devoted to Shoah, devoted to the camp, which it marginalises, is possible. At this point, in this text, I can only indicate the problem of the disparity and dissonance, which, applicable to Lagers and Shoah, Polish and Polish-Jewish literature, is important enough that without tackling it, any reliable synthesis of camp literature cannot be created in our country.

\section{Domestically and during emigration}

The camp in Borowski's prose is a dysfunctional outcome of the Mediterranean culture, of which the narrator of $U$ nas, $w$ Auschwitzu... considered himself a member. Therefore, the concentration catastrophe was for him something he did not consider as an event from another world. It was not only the problem of the West, but also his, a problem of a student of Polish studies at an underground university, an essentialist spending his time with his friends, a poet writing in Homer's hexameter, and a prisoner of Auschwitz. ${ }^{18}$

Warsaw 1948), yet one cannot use his play to exculpate the passivity of writers of Polish descent towards Shoah. Polish literature has been equally created by Polish and Polish-Jewish writers, and any indication of the literary problems of either of those groups should not be treated as something inappropriate. That remark applies as much to that which has already been stated above as to what will be stated.

${ }^{17}$ Vide Teksty Drugie 2004, issue 5.

${ }^{18}$ The story $U$ nas, $w$ Auschwitzu... is a unique text among other Borowski's prose pieces. The meticulously recreated letters to his fiancée, Maria Rundo, a Birkenau prisoner, which formed it, enabled reflections on the camp, virtually absent from the remaining, consistently behavioural texts. Regarding the meticulous recreation of the letters, vide "Pożegnanie z Tuśka.." Recorded by Krystyna Bratkowska and Michał Cichy, Gazeta Wyborcza 1995, issue 24. Regarding the "Essentialists' Club", vide T. Drewnowski, Ucieczka z kamiennego świata. O Tadeuszu Borowskim, $3^{\text {rd }}$ edition, PIW, Warsaw 1992, pp. 67-71, and J. Szczęsna, Tadeusz Borowski - poeta, PSP. Seria Literacka, 
Émigré literature mainly applies to gulags, and as such it cannot be easily summarised, or at least in a single camp synthesis. By simplifying the matter to a lesser extent, one could venture a statement that apart from the infrequent Lager exceptions (e.g. the non-camp/camp prose by Zofia Romanowiczowa) ${ }^{19}$ it copied the martyrological pattern known from the books by Seweryna Szmaglewska, Zofia Kossak, and Krystyna Żywulska published domestically immediately after WWII. ${ }^{20}$ In turn, it remains different from what Borowski wrote about Auschwitz. Émigré literature regarding gulags, e.g. the texts by Gustaw Herling-Grudziński, Beata Obertyńska, Józef Czapski, Herminia Naglerowa, and Wacław Grubiński, regardless of all their differences, offered the unifying awareness of recording a strange and alien world, different from the Western and the European worlds, i.e. civilised, the Eastern and Asian world, i.e. barbaric. While for Borowski, the camp was his own problem, his personal, civilisational failure, gulags were for Polish writers a problem which was external, someone else's, the consequences of which, in an inhuman land, we Poles were forced to heroically endure. Therefore, even in A World Apart and Na nieludzkiej ziemi, as well as in $W$ domu niewoli, and in Kazachstańskie noce and Między młotem i sierpem, there exists an overt and sometimes even irritating sense of superiority in relation to Soviet Russia. Because we, obviously, belong to the West, and we remember 1920 well.

Under the same caption it would be possible to discuss everything, yet the differences between domestic Lager literature dominated by Borowski's prose, and the broadly understood émigré Gulag literature (regarding the fortunes of Poles in the USSR from 1939 to at least 1956) ${ }^{21}$ seem so fundamental that it would be difficult to expect a literary science synthesis discussing them as a whole. And that is only one of the three basic reasons hindering or even rendering impossible the creation of a synthetic historical and literary study of Polish camp literature. That does not mean, though, that nothing can be done in that respect.

\section{What can be done}

It seems that Lager and Gulag literatures need to be discussed separately, yet the position requires verification in practice. For the time being, it is worth focussing on Lager literature, which lacks a synthesis; it is worth organising it both

Poznań 2002, pp. 13-16. The series/collection entitled Gdziekolwiek ziemia... written in hexameter were discussed both by Drewnowski and Szczęsna.

${ }^{19}$ Vide, e.g. ibid.: Przejście przez Morze Czerwone, Lagodne oko błękitu, Trybulacje probosz$c z a P$.

${ }^{20}$ Vide S. Szmaglewska, Dymy nad Birkenau, Czytelnik, Warsaw 1945; Z. Kossak, Z otchtani. Wspomnienia z lagru, Wydawnictwo Księgarni Wł. Nagłowskiego, Częstochowa-Poznań 1946 (and altered version: Warsaw 1958); K. Żywulska, Przeżytam Oświęcim, Wiedza, Warsaw 1946.

${ }^{21}$ Vide, e.g. B. Skarga, Po wyzwoleniu... (1944-1956), $2^{\text {nd }}$ edition domestic, W drodze, Poznań 1990. First printed in Paris, under the nom de plume Wiktoria Kraśniewska: 1985. 
based on the criteria of extra-literary and literary natures. I propose to divide the former into historical (which camps and when?), and geographical (where?); the latter should consider issues periodisational (which camp texts and when?), genological (why non-epic prose?), and comparative (Polish camp literature in relation to camp literatures by Russians, Hungarians, and Italians).

\section{Extra-literary criteria: historical and geographical}

Which camps? Nazi concentration camps (from Smoke... by Szmaglewska to Borowski, this area offers the most examples), DP camps (Borowski, Obóz Wszystkich Świętych by Tadeusz Nowakowski of 1957, Dziennik podróży do Austrii $i$ Niemiec by Paweł Hostowiec, a.k.a. Jerzy Stempowski of 1946), but also POW camps (Kłamałem, aby żyć by Aleksander Janty-Połczyński of 1945), and Nazi labour camps (e.g. "Strach" from the Wielki cien' collection by Jerzy Pytlakowski of 1946), as well as camps in which the inhabitants of Warsaw were interned upon the fall of the Warsaw Uprising (e.g. Wody z Wielkiego cienia or the third fragment of Próba śmierci from the Śmiertelni bohaterowie collection by Witold Zaleski of 1946). ${ }^{22}$

There is a problem with the limits of the application of that criterion as, e.g. what should one do with the prisons described in Krata by Pola Gojawiczyńska (1945), or in the text Dwadzieścia cztery godziny śmierci by Pytlakowski (Wielki cień once again)? It is not solely a theoretical issue as it results from the reading of such works as Szopa za jaśminami by Nowakowski (1948), which described not only a Nazi prison in Włocławek, but also a prison in Zwickau (a Gestapo-established co-ed store for particularly dangerous political prisoners), a Gestapo transitional camp in Inowrocław, and a penal camp Elsnig-Vogelgesang on the Elbe.

Such problems could be, actually, listed endlessly. Yet I prefer to write that preparing a synthesis fulfilled according to the proposed criteria enables one to avoid the domination of Borowski's prose, completely paralysing any evaluation of Polish camp literature. That is the case because the starting point for synthesising is historical-geographical, not evaluative-literary organisation. Thanks to that, it is possible to place in one location not only Pożegnanie z Maria, and the martyrological domestic Smoke over Birkenau, but also émigré texts, both camp ones (Nowakowski, Hostowiec, Janta-Połczyński) and Gulag ones, regardless even of the fact that initially they were not to be included in the synthesis. Actually, if it is to consider POW camps, then apart from Połczyński's novel and Zalewski's prose, it should include Wspomnienia starobielskie by Czapski. A similar issue applies to Nazi labour camps, the discussion of which naturally requires the context of similar camps which operated in Soviet Russia, and were described by the

\footnotetext{
${ }^{22}$ The first fragment of Próba śmierci discusses an uprising hospital, the second: a POW camp.
} 
already-mentioned authors of Gulag literature, among whom - because of Ksiązka o Kotymie of 1950 - Anatol Krakowiecki should be considered.

The history of the Gulag is still being told and supplemented. More and more people are switching from reading The Gulag Archipelago by Aleksandr Solzhenitsyn to Gulag by Anne Applebaum. ${ }^{23}$ As a result, gulags have received their own history, which the Nazi camps do not possess. ${ }^{24}$ Therefore, it seems paramount to organise and record the basic historical knowledge which applies to Lagers. That applies not only to their types, but also their geography as very few remember that during WWII Poland not only lost Kresy Wschodnie, but also the territory in the west, out of which the Germans created The Reichsgau Wartheland by annexing it to the Reich. And who of us can precisely define the borders of the General Government? The issue is not only the historic geography, but also in which jurisdiction KL Auschwitz-Birkenau was located. Was it in the lands annexed by the Reich or in the GG? Bear in mind that the distance between Oświęcim and Krakow, the capital of the General Government, is less than 60 kilometres.

The literary map can consider the administrative division of occupied Poland in 1939-1945, or the pre-WWII and/or post-Yalta borders of our country. We already know that Lagers from Auschwitz to Munich in the south of Germany (Central European and West European) were best recorded by Borowski; the gulags of the eastern, Soviet, Eurasian territory were most successfully recorded in the texts by Grudziński, Czapski, and Obertyńska (i.a. the Urals and Uzbekistan), and Krakowiecki (Kolyma); $;{ }^{25}$ camps in Central Europe which operated between the Vistula and the Elbe within the east-west axis (both during and after WWII) were the domain of Tadeusz Nowakowski's prose; the location furthest to the west in this map was defined by the autobiographical novel by Janta-Połczyński, in which he recorded the fortunes of French soldiers and Poles imitating them, who were interned by Nazi Germany.

${ }^{23}$ Vide A. Appelbaum, Gułag, trans. J. Urbański [chapter 1 - M. Claire Wybieralska], Świat Książki, Warsaw 2005, and A. Sołżenicyn, Archipelag GUŁag 1918-1956. Próba analizy literackiej, parts 1-2, trans. M. Kaniowski, Instytut Literacki, Paris 1974. Vide also T. Kizny, Gułag, cooperation D. Roynette, introduction N. Davies, S. Kowalow, N. Werth, IPN - Komisja Ścigania Zbrodni przeciwko Narodowi Polskiemu, Fundacja Pictura Doc, Warsaw 2015.

${ }^{24}$ It is the publication approved by the Chief Commission for Investigating Nazi Crimes in Poland (Główna Komisja Badania Zbrodni Hitlerowskich w Polsce) and by The Council for the Protection of Struggle and Martyrdom Sites entitled Obozy hitlerowskie na ziemiach polskich 1939-1945. Informator encyklopedyczny (Warsaw 1979), yet despite all its advantages, it was developed in an epoch when the entry on Nazi camps in Wielka encyklopedia powszechna of 1967 was altered under the influence of Moczar's group, as it discussed Jews too extensively. Vide Czas ciekawy, czas niespokojny. Z Leszkiem Kołakowskim rozmawia Zbigniew Mentzel, Znak, Krakow 2007, part 1, p. 256.

${ }^{25}$ Grudziński is the most important author of Polish Gulag literature. Czapski's books defined the core of the fortunes of Polish POWs, inevitably associated with the Katyń massacre. Beata Obertyńska recorded in her prose, $W$ domu niewoli, the typical fortunes of the Polish intelligentsia of the borderlands (from Lviv in that case), sentenced by the Soviet authorities after 17 September 1939 to exile, prison, and slave labour. Ksią̇ka o Kolymie by Anatol Krakowiecki is a text intentionally devoted to the biggest complex of labour camps, educational in nature, naturally, in Soviet Russia. 


\section{Literary criteria: genology}

The historical-geographical map of camp texts is the first basic step towards a synthesis of Polish Lager, Gulag and camp literature. A condition of the historical-literary nature of the project is to consider in it criteria of a literary nature. Allow me to begin with genology as there is no point in avoiding the obvious assertion that Polish camp literature consists mainly of prose. Camp poetry cannot compete with it. That is visible not only when one juxtaposes Polish camp poetry with Polish camp prose, but also when the same genre comparison is done within specific outputs, i.e. the outputs of such major writers as Tadeusz Borowski and Beata Obertyńska.

Borowski's camp poems ${ }^{26}$ cannot compete with his camp prose. Gulag poetry by Obertyńska, ${ }^{27}$ the author of $W$ domu niewoli, the most epic story of not only the camp ordeal of Poles in the East, also loses importance when compared to her Gulag prose. Both Obertyńska and Borowski until their camp experiences, were more known as poets, yet Borowski, even as the co-author of Byliśmy w Oświęcimiu, only considered his poetry in literary terms. ${ }^{28}$ There is no need to decide which of the types of literature, be it prose or poetry, is more adequate for the camp experience. It should suffice to state that for this purpose, prose proved more capable than poetry, while adding the following side note: it might be possible that the martyrological-messianic patterns of Romantic provenance Polish literature used (or has been using) in relation to historic failures, proved after WWII more durable in poetry than in prose, which has been less tamed by Romanticism. Yet that explanation, useful in the case of the anti-Romantic Borowski, ${ }^{29}$ falls short in the face of the genetically Romantic martyrological camp literature. There is also the possibility that the superiority of prose was rather caused by the practice, and actually both literary: behavioural camp prose by Borowski, and moral: the natural inclination of the (post)camp community to record their memories in the form of prose rather than poetic texts.

Having established that it is prose, the question emerges: what kind? Firstly, not to always begin with Borowski, a novel with epic ambitions, striving to cover the entire camp experience, i.e. Smoke over Birkenau domestically, and $W$ domu niewoli during emigration. Furthermore, $A$ World Apart by Grudziński, $Z$ otchłani

${ }^{26}$ Vide T. Borowski, "Księga z dnia Wigilii”, in: ibid., Poezja, T. Drewnowski, J. Szczęsna (eds.), Wydawnictwo Literackie, Krakow 2003.

${ }^{27}$ Vide B. Obertyńska, "Wiersze z łagrów”, in: ibid., W domu niewoli, PAX, Warsaw 1991. Originally printed in: 1946.

${ }^{28}$ I wrote on it quoting Borowski's letters in a book entitled Dwie prawdy..., op. cit., p. 102.

${ }^{29}$ Bearing in mind the interpretative ideas by T. Drewnowski reading the character of Vorarbeiter Tadek in the context of Konrad's Improvisation gestures in Forefathers' Eve, Part III, I discussed the anti-Romantic Borowski in my conference paper entitled Tadeusz Borowski. Antyromantyczny poczatek literatury polskiej po wojnie, used in Dwie prawdy, op. cit., pp. 62-76. 
by Kossak, the most complete edition of Na nieludzkiej ziemi by Czapski (1990), which apart from the title texts, also included Wspomnienia starobielskie, and Wal$k a$ written with German readers in mind, Przeżyłam Oświęcim by Żywulska, and Książk o Kotymie by Krakowiecki. Immediately after those, there are collections of short stories and stories, which distributed their camp entirety into texts related to one another through a personal narrator (Borowski), aesthetics referring to, e.g. Roman monuments, ${ }^{30}$ or the chronology of the events being described: Herminia Naglerowa and her Kazachstańskie noce (1958). There also remain camp-themed short stories and stories, which constituted part of the prose volumes popular immediately after WWII, the authors of which strove to record the wartime-occupation reality through texts related to key events of 1939-1945. ${ }^{31}$ The two most significant examples: "Apel" by Andrzejewski in the Noc (1945) collection, and "Kantata" by Wojciech Żukrowski in the Z kraju milczenia (1946) collection.

Having realised that Polish camp literature consists not only of poetry, but also prose, both epics and novels,${ }^{32}$ one must inquire about drama, i.e. camp plays written domestically and during emigration. There is not much to be indicated. ${ }^{33}$ The domestic plays by Ireneusz Iredyński (e.g. the directly camp-located Jasetka-moderne, printed in 1962, staged in 1965, or Zejście do piekta, indirectly discussing the camp, staged in 1964) ${ }^{34}$ said more about the world after WWII using Lagers for describing it than about Lagers themselves. Tadeusz Hołuj approached the Lager in a similar, i.e. instrumental, fashion. In Dom pod Oświęcimiem (1948), he focussed more on the psychology of his characters than on the camp reality, while his Puste pole of 1963 was a play presenting everything bad (and sensationalistic) happening within the area of an undefined former Lager when a museum is being set up there. Stara gwardia by Mieczysław Lurczyński ${ }^{35}$ is much more camp-focussed, though its author has remained for the majority of those

${ }^{30}$ Vide G. Morcinek, Listy spod morwy (Sachsenhausen-Dachau), $2^{\text {nd }}$ edition, Literatura Polska, Katowice 1946. Originally printed in: 1945, and ibid., Listy z mojego Rzymu, Biuro Prasowe Biskupa Polowego W.P., Rome 1946.

${ }^{31}$ The standard theme composition of such collections included September 1939, concentration camps, the Holocaust, and the Warsaw Uprising.

${ }^{32}$ The best short stories within Polish camp literature were, once again, written by Borowski, i.e. Lager and DP-themed texts from Kamienny świat.

${ }^{33}$ Drama is a literary kind which, unlike prose and poetry, was rarely chosen for recording camp memories or creating camp literature.

34 "Directly" because Jasełka-moderne occurs in the camp. "Indirectly" as Zejście do piekta applies to a Lager organised in a Brazilian jungle by the Nazis who fled from Europe. I excluded from the list a camp that people from a community described by Iredyński in a play entitled Trzecia pierś (first printed in 1973, premièred in that same year in Zurich, Polish première: 1975) dealt themselves.

${ }^{35}$ Vide essay: A. Morawiec, “«Niech ludzie sądzą». O dramacie «Stara gwardia» Mieczysława Lurczyńskiego", in: Paryż - Londyn - Monachium - Nowy Jork. Powrześniowa emigracja niepodległościowa na mapie kultury nie tylko polskiej, V. Wejs-Milewska and E. Rogalewska (eds.), Trans Humana, Białystok 2009. 
who have even come into contact with his output rather a poet and a prose writer, and rather associated with drama through the introduction to Pierścien wielkiej damy by Cyprian Kamil Norwid ${ }^{36}$ than his obscure camp play. Therefore, it would be difficult to assume that drama, similarly to poetry, could offer any genological competition for prose: which is most important from the point of view of Polish camp literature. That does not change the fact that it is necessary to consider in the synthesis all plays and the entire poetry on the camps. Even what just like Lager and Gulag prose constitutes mainly evidence of camp fortunes, regardless of its value in literary terms. ${ }^{37}$

\section{Periodisation}

The most valuable texts, in literary and historical terms, of Polish camp literature were written in 1944-1948..$^{38}$ Major exceptions include $A$ World Apart by Herling-Grudziński, first published in English in 1951, and later in Polish in 1953, and Obóz Wszystkich Świętych by Tadeusz Nowakowski published in 1957. Some apparent exceptions include Kazachstańskie noce by Naglerowa (1958); which includes texts from the Ludzie sponiewierani (1945) collection, and Na nieludzkiej ziemi by Czapski: prose, the fullest edition of which, which I had already mentioned, was published as late as 1990, yet the first edition was released in 1949, and it included Wspomnienia starobielskie of 1944.

The turn of 1956 did not offer camp literature any new items apart from the controversial, not only in terms of its aesthetics, book by Stanisław Grzesiuk entitled Pięć lat kacetu (1958). The 1960s, or - according to Stanisław Burkot - the third wave of literature's interest in WWII and occupation, ${ }^{39}$ featured in terms of the Lager only Trismus by Stanisław Grochowiak (1963). In the 1960s and the early-1970s, the camps appeared in the plays by Ireneusz Iredyński, which I have

${ }^{36}$ Vide C. Norwid, Pierścień wielkiej damy. Tragedia w 3-ch aktach, with an introduction by M. Lurczyński, Polski Związek Wychodźctwa Przymusowego, Hanover 1945.

${ }^{37}$ At this point I would like to add that I do not intend to decide whether it was Bartłomiej Krupa who was right in indicating the value of all, even that unconvincing in literary terms, camp evidence, or Włodzimierz Bolecki in demanding during a Polish Researchers' Symposium in 2004 exclusive presence of literary texts in the, rather ironically, literary science studies regarding Lagers and Gulags. I will only state what seems obvious to me: the biggest amount of knowledge on the camps is offered by belles-lettres. That knowledge enables both moral and historic evaluation of the camps. That rule also applies to those texts which - initially, at least, as in the case of Borowski's Lager prose - were written independently of any grand consciously prepared and consistently fulfilled literary ambitions. Historians, and others, may have a different opinion on that matter.

${ }^{38}$ Suffice to consider the dates of the texts, to which I most often refer in this text. In addition, the diagnosis applies both to domestic and émigré literature.

${ }^{39}$ Vide S. Burkot, Proza powojenna $1945-1987,2^{\text {nd }}$ edition amended, Wydawnictwa Szkolne i Pedagogiczne, Warsaw 1991, p. 66. 
already mentioned. However, what seems more important is the fact that the interest in the wartime-occupation topic, which re-emerged in the early-1970s, avoided the camp theme..$^{40} 1975$ was a breakthrough year in prose, yet its postmodern and oppositional consequences were focussed neither on Lagers nor Gulags. ${ }^{41}$

After 1989, the division into domestic and émigré literature became idle because in the book market there emerged legally published texts by émigrés also regarding the Gulag theme..$^{42}$ From the perspective of 2016, three other extremely diverse phenomena seem much more significant for the image of camp literature after 1989. The first was the grand return of the Holocaust literature ${ }^{43}$ written by domestic writers and those who left Poland after WWII. The topic of Shoah, which accompanied Polish literature from the stories by Adolf Rudnicki and the series by Artur Sandauer, through the plays by Julian Styjowski, the domestic Jewish war of Henryk Grynberg, or the reports by Hanna Krall, boomed after 1989, not only thanks to Polish writers of Jewish descent, among whom one could list such names as Roma Ligocka and Michał Głowiński, but also Jewish writers: Irit Amiel and Ida Fink. The camp has not played a leading role in those writings.

The same applies to texts considered as post-memory literature. Major works there include: Fabryka mucholapek by Andrzej Bart (2008), and Tworki by Marek Bieńczyk (1999), though they either tell the stories related to the Łódź ghetto, or utilise the distinct metaphor of a psychiatric hospital, they do not co-create camp belles-lettres, which, in fact, should not seem disturbing if one considers the unwritten yet often applied rule that applies both to Lager and Gulag literatures, one

${ }^{40}$ Such major books as Pamiętnik z powstania warszawskiego (1970) or Chleb rzucony umartym (1971) applied to the camps. In the case of Miron Białoszewski's prose, that was the transitional camp in Pruszków, to which he was sent together with his loved ones after the fall of the Uprising. In Wojdowski's case one cannot omit the novel's final image of the termination of the Warsaw ghetto, which meant transporting the Jews who survived to the death camp in Treblinka. Nonetheless, neither of the books belongs to camp literature. The former, as noted by Maria Janion, introduced into Polish literature a civilian point of view on war, and enabled Białoszewski to return to, excuse my anachronism, the main stream of our culture. The latter should be mainly read as an exceptional epic story of the Warsaw ghetto from its establishment to its termination. What remains to be added is that the absence of the camps in the prose of the 1970s was accompanied by a return to the debate on Polish Gulag literature, as that was the time when the first editions of the monographs by A. Werner (1971) and T. Drewnowski (1972) devoted to Borowski were published.

${ }^{41}$ The information included in this paragraph applies solely to domestic literature. Within this period nothing significant for the shape of the image of the camps in Polish literature happened in terms of émigré literature, excluding the names and titles I have already mentioned (i.e. mainly Nowakowski and Naglerowa, also Lurczyński and Zofia Romanowiczowa).

${ }^{42}$ The already mentioned domestic editions of the prose of B. Obertyńska and J. Czapski, one must supplement mainly with $A$ World Apart, the first official domestic edition of which was released by Czytelnik in 1989.

${ }^{43}$ That is mainly prose, yet one could not omit the poems by Irit Amiel, as there is no reason to forget the Shoah-related poetry by H. Grynberg, who has been important for writing about Shoah before and after 1989 . 
which states that only reliable witnesses can offer proof: only those who experienced the camp.

Yet there is another dual reason specifying the mode in which Shoah has been present as a theme after 1989, which has not been accompanied by literature's interest in the camp theme. ${ }^{44}$ On the one hand, that applies to a special type of the lexicalisation of the concentration camp expression, which resulted in its use as a stylistic device, an allegory rather than a metaphor defining borderline situations (traumatic, dramatic, or simply difficult). ${ }^{45}$ On the other side of the equation, the camp is no longer a lexeme but a developed sign of culture signifying oppression, functional with the description of social sicknesses, also/especially contemporary ones. ${ }^{46}$

${ }^{44}$ Even a few years back, particularly before 2010, I would have written that the Holocaust was the only important and live wartime-occupation topic raised by Polish literature. (That would be significant, e.g. due to the absence of new literary studies of the camp theme.) Today, at the turn of 2017, one should notice the growing interest on the part of Polish poets in the fortunes of the so-called Banished Soldiers (Żołnierze Wyklęci). They were mentioned by, e.g. Wojciech Wencel and Przemysław Dakowicz, and their poems are significant enough that one could not omit them when inquiring about the place of WWII within contemporary Polish literature.

${ }^{45}$ For example: "Abandonment as a concentration camp" (A. Drotkiewicz, Paris, London, Dachau, Lampa i Iskra Boża, Warsaw 2004, p. 22) or: "trauma center, Sarah Kane, Roland Barthes, extermination camp, in a word: shitty" (ibid., p. 26). I used those quotations in a text entitled Bezradność. Polska proza wobec II wojny światowej, presented at the conference Pokój/wojna - humanistyka wobec wyzwań wspótczesności (Zielona Góra, November 2015). I used then also a fragment of a play by D. Masłowska entitled Między nami dobrze jest, in which the manner of talking about the camp practised by MAŁA METALOWA DZIEWCZYNKA suggests that she has no knowledge about the place. "MAŁA METALOWA DZIEWCZYNKA: Since grandma sits all day long in a house without a lift, she has no one to speak to, so when I come back from school, and I sit till the evening in front of the telly, I don't have the time to drive that old turd somewhere! My ponytails briskly fluttered in the wind as we didn't go through the autumn park, she was telling me her delicious stories of when she went to that concentration camp. In my opinion, she's somewhat ripping Czterej pancerni i pies or Allo, Allo off, but I'll let her have it. It's post-modernism, right?" (D. Masłowska, "Między nami dobrze jest", in: ibid., Dwa dramaty zebrane, Lampa i Iskra Boża, Warsaw 2010, p. 74). This time I shall supplement the collection of camp quotations with fragments of Jakub Żulczyk's novel, who was born in the same year as Masłowska, an author popular not only among the youngest readers. The first sentence refers to a high school teacher liked by students: "No one really knows what Miss Ania is talking about, but she looks like an actress who could play a nun feeding honey to escapees from concentration camps" (J. Żulczyk, Radio Armageddon, $2^{\text {nd }}$ edition amended, Świat Książki, Warsaw 2015, p. 31. Originally printed in: 2008). The second sentence: "Some people think that heroin dealers are bad, infected with the evil of concentration camp guards" (J. Żulczyk, Ślepnac od światet, Świat Książki, Warsaw 2014, p. 168). Despite the stylistic convention she uses, Masłowska treats the issue of the camp more seriously than Drotkiewicz. I would like to write the same about Żulczyk. I would.

${ }^{46}$ Just one example, yet spectacular and with an annex: Skaza by Magdalena Tulli (2006), a book in which the method of treating aliens (refugees, if you will) is presented using solutions known not only from the Germany of the 1930s, while the camp, especially the gas chamber, plays an important role in that story. Annex: A prose piece by Paweł Huelle "Szczęśliwe dni" from the Pierwsza miłość $i$ inne opowiadania collection (1996) evokes the issue of historic memory differently, especially the 
Polish literature still has not tackled the Holocaust, yet it recorded Lagers and Gulags so extensively in the years directly after WWII that the topic has never again become so important, and so excellently fulfilled in literary terms as was the case in 1944-1948. That does not, however, release a literary historian from asking about the relations between Polish post-WWII literature and Polish camp literature. ${ }^{47}$

\section{Comparative study}

Varlam Shalamov, Primo Levi, and Imre Kertész. A literary history synthesis of Polish camp literature should include material enabling one to confront the texts by Tadeusz Borowski and others at least with the Gulag/Lager output of the three above-mentioned writers. The first attempts have already been made. The author of Kolyma Tales and Borowski were discussed by Anna Łukowska, who was discouraged by the unilateral nature of the latter. ${ }^{48}$ The author of If This Is a Man was listed both by Magdalena Swat-Pawlicka, who analysed the case of the Muselmann within the concentration camp system, ${ }^{49}$ and Sławomir Buryła, who defined the relationship between Borowski's prose and the Holocaust, ${ }^{50}$ and those are not the only instances there are. Kertész appeared more often, yet just as in the case of the previous writer I shall refer only to two texts: another one from the themed issue of Teksty Drugie, ${ }^{51}$ and another one by Sławomir Buryła. ${ }^{52}$

It is easier to pose requirements regarding the following necessary studies in relation to the significance of what many have written, as that which is related to the camps neither was nor can be considered as solely Polish, while a synthesis discussing our Lager and Gulag literature is not only a stage preceding the formation of a study which is no longer solely European, but which considers camps which operated throughout the world, initially in 1939-1945. If the studies will

places occupied in it by the camps. The cars transporting people to Auschwitz appear in Huelle's text next to carriages of German DPs, and carriages of repatriated persons from the East. The intention behind it seems obvious: it was to restore our (national? European?) memory of those traumas of which one could not talk in the People's Republic of Poland. However, does that justified choice not result in a side effect of blurring the exceptionality of what happened in Auschwitz?

${ }^{47}$ In writing about Polish post-WWII literature I mean not only its core framed within the 1944-1989 period, but also contemporary literature since 1989.

${ }^{48}$ Vide A. Łukowska, "Borowski i Szałamow - dwie dole", Kultura Niezależna 1989, issue 52.

${ }^{49}$ Vide M. Swat-Pawlicka, "Z inkubatora systemu. Casus muzułmana w systemie koncentracyjnym”, Teksty Drugie 2004, issue 5.

${ }^{50}$ Vide S. Buryła, "Proza Tadeusza Borowskiego wobec Holocaustu", Ruch Literacki 2004, col. 3 .

${ }^{51}$ Vide J. Jastrzębska, "Imre Kertész - węgierski wariant dyskursu o Holocauście”, Teksty Drugie 2004, issue 5.

${ }^{52} \mathrm{~S}$. Buryła mentioned Kertész in the "Introduction" to the first volume of Proza by Borowski (Krakow 2004), defining him as being indebted to the author of Pożegnanie z Maria. 
consider contemporary references to the camps in world literature, they should result in the analyses of such quotes as well:

All right. It's that the world is basically a forced labor camp from which the workers-perfectly innocent-are led forth by lottery, a few each day, to be executed. I don't think that this is just the way I see it. I see it. I think it's the way it is. Are there alternate views? Of course. Will any of them stand close scrutiny? No. ${ }^{53}$

\section{Synthesis}

Not only is the history of literature as we know and remember it no longer possible, but also if one were to record it in relation to camp texts, one would encounter specific problems exclusively related to the specificity of that type of writing. Then again, should the urge to start (if not complete) a synthetic discussion of what applied not only to a phenomenon which has been constitutional for the post-WWII world, but also to the condition of human kind actually seem surprising? I believe that there is no other choice but to tackle the impossible if a historical and literary synthesis of Polish camp literature is actually unwritable. It is still possible to draw a literary map of the camps: those identified and named, which operated in 1939-1945, within the pre-WWII or at least the post-WWII territory of Poland. Similarly within our reach there remains the task of collecting the entire camp literature written in Polish: domestic, émigré, reliable in literary terms, and fulfilling the function of a quasi-literary testimony.

We are also ready to analyse that material as we have seen and produced priceless works which have defined the cultural (community and editorial) context of camp literature (Drewnowski), we possess excellent interpretations of it (Werner, Zygmunt Ziątek), ${ }^{54}$ and convincing deconstructions of those (Krzysztof Kłosiński) ${ }^{55}$ and if someone finds it troubling that the offered examples mainly refer to Borowski (because martyrological literature as well), there is the stipulation by Bartłomiej Krupa, who demanded the reading of camp texts as a material enabling the construction of a structuralist-community model of what a Lager is.

Is that inventory sufficient to overcome the reasons why a synthesis of Polish camp literature has not been created yet? The significance of Borowski's Lager prose remains the reason why a synthesis seems redundant, while the differences between camp literature written domestically and during emigration suggest it is

${ }^{53}$ C. McCarthy, Sunset Limited. Powieść w formie dramatu, trans. R. Sudół, Wydawnictwo Literackie, Krakow 2013, p. 102. [English version: McCarthy, Cormac. The Sunset Limited. Knopf Doubleday Publishing Group. Kindle Edition.] First printed in the US: 2006.

${ }^{54}$ Vide Z. Ziątek, “«Pamięć przechowuje tylko obrazy». Tadeusz Borowski”, in: Sporne postaci polskiej literatury wspótczesnej, A. Brodzka (ed.), Wydawnictwo IBL, Warsaw 1994.

${ }^{55}$ Vide K. Kłosiński, "Proszę państwa do gazu”, in: ibid., W strone inności. Rozbiory i debaty, Wydawnictwo Uniwersytetu Śląskiego, Katowice 2006. 
impossible. What is left is the Holocaust: unrecorded by "Polish writers of Polish descent". It is the reason why a synthesis seems necessary, because a study of it will emphatically indicate the lack of camp texts which consider the exceptional fate of the Jews. Even if completed, the task will not change the condition of literature, and as such it might seem unnecessary. ${ }^{56}$ Yet one needs to try: both in order for the synthesis to be created, and for us to remember. If, however, an historical and literary synthesis of Polish camp literature would release us from the obligation to remember, it would be better for no one to write it at all.

\section{Bibliography}

Amiel Irit, Egzamin z Zagłady, Oficyna Bibliofilów, Łódź 1994.

Amiel Irit, Nie zdążyłam, Oficyna Bibliofilów, Łódź 1998.

Amiel Irit, Wdychać głęboko, Świat Literacki, Izabelin 2002.

Applebaum Anne, Gułag, trans. Jakub Urbański [chapter 1 - Małgorzata Claire Wybieralska], Świat Książki, Warsaw 2005.

Białoszewski Miron, Pamiętnik z powstania warszawskiego, Państwowy Instytut Wydawniczy, Warsaw 1970.

Borowski Tadeusz, Pisma w czterech tomach, Tadeusz Drewnowski, Justyna Szczęsna, Sławomir Buryła (eds.), Wydawnictwo Literackie, Krakow 2003-2005.

Borowski Tadeusz, Utwory zebrane, Jerzy Andrzejewski (chief ed.), vol. 3: Krytyka literacka $i$ artystyczna, Państwowy Instytut Wydawniczy, Warsaw 1954.

Broszkiewicz Jerzy, Oczekiwanie, Wiedza, Warsaw 1948.

Burkot Stanisław, Proza powojenna 1945-1987, $2^{\text {nd }}$ edition amended, Wydawnictwa Szkolne i Pedagogiczne, Warsaw 1991.

Buryła Sławomir, "Proza Tadeusza Borowskiego wobec Holocaustu”, Ruch Literacki 2004, col. 3, pp. 293-307.

Czaplejewicz Eugeniusz, Polska literatura łagrowa, PWN, Warsaw 1992.

Czas ciekawy, czas niespokojny. Z Leszkiem Kołakowskim rozmawia Zbigniew Mentzel, part 1, Krakow 2007.

Czuchnowski Marian, Tyfus, teraz słowiki, Modern Writing, London 1951.

Dakowicz Przemysław, Łącza, Arcana, Krakow 2013.

Drewnowski Tadeusz, Literatura polska 1944-1989. Próba scalenia: obiegi - wzorce - style, $2^{\text {nd }}$ edition amended, Universitas, Krakow 2004.

Drewnowski Tadeusz, Próba scalenia. Obiegi-wzorce - style, PWN, Warsaw 1997.

Drewnowski Tadeusz, Ucieczka z kamiennego świata. O Tadeuszu Borowskim, $3^{\text {rd }}$ edition, Państwowy Instytut Wydawniczy, Warsaw 1992.

Drotkiewicz Agnieszka, Paris, London, Dachau, Lampa i Iskra Boża, Warsaw 2004.

Grynberg Henryk, Rysuję w pamięci, a5, Poznań 1995.

Herling-Grudziński Gustaw, Inny świat. Zapiski sowieckie, Czytelnik, Warsaw 1989.

Huelle Paweł, "Szczęśliwe dni”, in: ibid., Pierwsza miłość i inne opowiadania, Puls, London 1996.

${ }^{56} \mathrm{I}$ do not know whether a synthesis indicating what is missing will induce writers to fill that gap. The problem is not only of the persuasive (in)efficiency of historical and literary diagnoses, but also (mainly?) that there are fewer and fewer camp survivors who could write about it considering the exceptional nature of the fate of the exterminated Jews. The literature of post-memory does not seem sufficient in this case. 
Janion Maria, "Wojna i forma”, in: ibid., Ptacz generała. Eseje o wojnie, Sic!, Warsaw 1998, pp. 23-126. Article first printed in: 1976.

Jastrzębska Jolanta, "Imre Kertész - węgierski wariant dyskursu o Holocauście”, Teksty Drugie 2004, issue 5, pp. 152-167.

Kizny Tomasz, Gułag, collaborator Dominique Roynette, introduction Norman Davies, Sergey Kovalev, Nicolas Werth, IPN - Komisja Ścigania Zbrodni przeciwko Narodowi Polskiemu, Fundacja Picture Doc, Warsaw 2015.

Kossak Zofia, Z otchłani. Wspomnienia z lagru, Wydawnictwo Księgarni Wł. Nagłowskiego, Częstochowa-Poznań 1946.

Kossak Zofia, Z otchłani, PAX, Warsaw 1958.

Kraśniewska Wiktoria, Po wyzwoleniu... (1944-1956), Instytut Literacki, Paris 1985.

Krupa Bartłomiej, Wspomnienia obozowe jako specyficzna odmiana pisarstwa historycznego, Universitas, Krakow 2006.

Kulesza Dariusz, Dwie prawdy. Tadeusz Borowski i Zofia Kossak wobec obrazu wojny w polskiej prozie lat 1944-1948, Trans Humana, Białystok 2006.

Kulesza Dariusz, W poszukiwaniu istoty rzeczy. Studia i portrety, Alter Studio, Białystok 2015.

Łukowska Anna, "Borowski i Szałamow - dwie dole", Kultura Niezależna 1989, issue 52, pp. 42-64.

Masłowska Dorota, "Między nami dobrze jest", in: ibid., Dwa dramaty zebrane, Lampa i Iskra Boża, Warsaw 2010.

McCarthy Cormac, Sunset Limited. Powieść w formie dramatu, trans. Robert Sudół, Wydawnictwo Literackie, Krakow 2013. First printed in the US: 2006.

Morawiec Arkadiusz, “«Niech ludzie sądzą». O dramacie «Stara gwardia» Mieczysława Lurczyńskiego", in: Paryż - Londyn - Monachium - Nowy Jork. Powrześniowa emigracja niepodległościowa na mapie kultury nie tylko polskiej, Violetta Wejs-Milewska and Ewa Rogalewska (eds.), Trans Humana, Białystok 2009, pp. 655-679.

Morcinek Gustaw, Listy spod morwy (Sachsenhausen-Dachau), $2^{\text {nd }}$ edition, Literatura Polska, Katowice 1946.

Morcinek Gustaw, Listy z mojego Rzymu, Biuro Prasowe Biskupa Polowego W.P., Rome 1946.

Morka Andrzej, Doświadczenie Boga w Gułagu, Wydawnictwo Diecezjalne, Sandomierz 2007.

Norwid Cyprian, Pierścień wielkiej damy. Tragedia w 3-ch aktach, with an introduction by M. Lurczyński, Polski Związek Wychodźctwa Przymusowego, Hanover 1945.

Obertyńska Beata, $W$ domu niewoli, PAX, Warsaw 1991

Obozy hitlerowskie na ziemiach polskich 1939-1945. Informator encyklopedyczny, PWN, Warsaw 1979.

Pankowski Marian, Z Auszwicu do Belsen. Przygody, Czytelnik, Warsaw 2000.

Pisarze polsko-żydowscy XX wieku. Przybliżenia, M. Dąbrowski and A. Molisak (eds.), Elipsa, Warsaw 2006.

"Pożegnanie z Tuśką." Recorded by Krystyna Bratkowska and Michał Cichy, Gazeta Wyborcza 1995, issue 24, pp. 14-16.

Romanowiczowa Zofia, Łagodne oko błękitu, Libella, Paris 1968.

Romanowiczowa Zofia, Przejście przez Morze Czerwone, Libella, Paris 1960.

Romanowiczowa Zofia, Trybulacje proboszcza P., Algo, Archiwum Emigracji, Torun 2001.

Rudnicki Adolf, Szekspir, Książka, Warsaw 1948.

Sandauer Artur, O sytuacji pisarza polskiego pochodzenia żydowskiego w XX wieku (rzecz, która nie ja powinienem byt napisać...), Czytelnik, Warsaw 1982.

Sariusz-Skąpska Izabella, Polscy świadkowie GUŁagu. Literatura łagrowa 1939-1989, $3^{\text {rd }}$ edition, Universitas, Krakow 2012.

Skarga Barbara, Po wyzwoleniu... (1944-1956), $2^{\text {nd }}$ edition domestic, W drodze, Poznań 1990.

Solzhenitsyn Aleksandr, Archipelag GUŁag 1918-1956. Próba analizy literackiej, parts 1-2, trans. Michał Kaniowski, Instytut Literacki, Paris 1974. 
Swat-Pawlicka Magdalena, " $Z$ inkubatora systemu. Casus muzułmana w systemie koncentracyjnym", Teksty Drugie 2004, issue 5, pp. 64-77.

Szczęsna Justyna, Tadeusz Borowski - poeta, PSP. Seria Literacka, Poznań 2002.

Szmaglewska Seweryna, Dymy nad Birkenau, Czytelnik, Warsaw 1945.

Teksty Drugie 2004, issue 5.

Tulli Magdalena, Skaza, W.A.B., Warsaw 2006.

Wencel Wojciech, De profundis, Arcana, Krakow 2010.

Werner Andrzej, Zwyczajna apokalipsa. Tadeusz Borowski i jego wizja świata obozów, Czytelnik, Warsaw 1971.

Wojdowski Bogdan, Chleb rzucony umartym, Państwowy Instytut Wydawniczy, Warsaw 1971.

Wojdowski Bogdan, "Judaizm jako los", Puls 1993, issue 3, pp. 67-78.

Żulczyk Jakub, Radio Armageddon, $2^{\text {nd }}$ edition amended, Świat Książki, Warsaw 2015.

Żulczyk Jakub, Ślepnac od światet, Świat Książki, Warsaw 2014.

Żywulska Krystyna, Przė̇yłam Oświęcim, Wiedza, Warsaw 1946.

\section{Polish camp literature. A few questions about a synthesis that is missing}

\section{(Summary)}

The author of the text poses questions why there has never been a historical and literary synthesis regarding Polish camp literature, Lager-themed in particular, as Gulag literature possesses at least protosyntheses. He presents his answers which refer to the significance of Tadeusz Borowski's camp prose, the exceptionality of the Holocaust, and the differences in recording the camp experience domestically and during emigration. What is most important in the article is the indication of the opportunities available today, regardless of the virtually impossible to overcome difficulties, for at least a preliminary synthesis of Polish camp literature to exist. The starting point for that postulate is the application of external criteria: historical-geographical (which camps, when and where?), and historical and literary considering such categories and study perspectives as periodisation, genology, and comparative study.

Key words: Polish camp literature, historical and literary synthesis, Tadeusz Borowski, the Holocaust 